\title{
MICROFINANCE AND MICROFINANCE INSTITUTIONS - DEVELOPMENT DIRECTIONS AND PROSPECTS
}

\section{PRZEMYSŁAW PLUSKOTA}

University of Szczecin, POLAND

e-mail: przemyslaw.pluskota@wzieu.pl

\section{RECEIVED \\ ACCEPTED \\ JEL \\ CLASSIFICATION}

KEYWORDS

ABSTRACT

\section{April 2018}

12 July 2018

G21, G23

microfinance, microcredit, microfinance institutions

In the EU terminology, microfinance is defined as a tool to provide impoverished people with a basic access to financial services in the form of loans, savings, money transfers and microinsurance. From the economic point of view, the idea of microfinance should not be any substantial problems with sourcing the capital to support the poorest people who are excluded from the society. If the capital market were ideally flexible, the poorest people should not suffer from lack of capital. The factor that contributes to the fact that capital is not invested in the poorest regions of the world is also the substantially higher cost related to investments made by the poor and unequal access to information (information asymmetry), which leads to negative selection, moral hazard and difficulties with monitoring.

In many EU countries, microfinance institutions have been functioning successfully, while the number as well as the value of granted microloans has been rising. Summing up the deliberations regarding the idea and operation scopes of microfinance institutions, it may be said that they are gaining importance not only on the financial market, but first and foremost in social and economic development of many countries and regions, in the developing countries as well as in Europe and in Poland. To enable further growth of microfinance, in view of the achievements made so far by the sector, it is possible to propose scenarios and directions of development with regard to the source of the loan capital. The solution appears to consist of the three scenarios of microfinance institutions development: commercial scenario, social scenario, mixed scenario. The scenarios may neglect some aspects of their operations. Still, they indicate the directions which microfinance institutions may follow and point to those that are the most desirable from both social and economic point of view, also taking into account the local development aspect. 


\section{Introduction}

Microfinance tends to be perceived as financial services for impoverished and low-income people. It is often identified with loans that are granted without collaterals and on the principle of group liability, and when they are repaid as expected, they may open up a possibility of obtaining further, bigger loans (Gonzalez, Rosenberg, 2006). The concept of microfinance is very often equated to microcredit and many a time both terms are used interchangeably. In fact, however, the scope of microfinance is much broader, as it is not only microcredits (even though they constitute a major part of each product range of microfinance institutions), but also a wide assortment of other financial services, such as credit, deposit, insurance, and transfer services offered to the poor and to micro-enterprises, which provides them with a possibility of obtaining or increasing their income, and in many cases of improving the living standard of whole families (Adamek, 2010, p. 25).

In the EU terminology, microfinance is associated with M. Yunus and his Grameen Bank, and defined as a tool to provide impoverished people with a basic access to financial services in the form of loans, savings, money transfers and microinsurance. Like anybody else, people who live in poverty need access to a broad range of financial services in order to be able to run their business activity, accumulate their assets or actively and effectively manage their risks (Microcredit Networks..., 2010, p. 13). Over the years, operations of microfinance entities have evolved from the one relying on grants and subsidies from microcrediting institutions to the model that offers a wider scope of services - above all including deposit products. Apart from micro-crediting, EU microfinance institutions offer services to support business activity, trainings, and financial education programs, or they have business incubators incorporated into their structures (Bending, Unterberg, Sarpong, 2012, p. 37).

Over the recent years, development of the microfinance market and sustaining its stability have become a major challenge and an element of many activities, debates and various initiatives. This gained particular importance in the context of mitigating the financial crisis effects. The role and importance of microfinance institutions are confirmed by various examples of their activities, their impact on the financial market and the situation of individual business entities. Their significance is also proved by analyses and studies that indicate the increasing role and importance of microfinance in sustaining the financial system stability (Alińska, 2017, p. 26).

The aim of this article is to present the idea of microfinance, its significance and reasons for existence, as well as microfinance institutions functioning. The developments regarding the idea of providing help to the poorest and the ensuing effects have made it necessary to indicate new, optimum directions of development, first and foremost with respect to microfinance entities.

\section{The reasons for microfinance existence}

From the economic point of view, the idea of microfinance should not be hard to implement and there should not be any substantial problems with sourcing the capital to support the poorest people who are excluded from the society. If the capital market were ideally flexible, the poorest people should not suffer from lack of capital. This could be explained by means of the law of diminishing marginal returns of capital, according to which each subsequent unit of capital engaged in the production process will bring less and less return in the form of sales revenues. Therefore, entrepreneurs having lower amounts of capital are able to generate higher revenues, compared to those with capitals of higher value. This in turn means that the former are able to pay higher interest than the latter 
due to the theoretical possibility of generating more revenues. Consequently, any entities that operate small-scale production should not be troubled by lack of capital.

Research studies regarding the reasons for insufficient capital flows to the poorest countries were taken up by, inter alia, P.J. Montiel and W. College (2006) who analysed the Lucas Paradox using the example of Africa. They divided the potential factors into two groups. The first group included the too small number of projects characterised by a satisfactory rate of return. The second group featured the structural factors that are very difficult to overcome in a short term, such as in particular human capital and public sector management quality, caused by the macroeconomic instability in those countries (Montiel, 2006, pp. 27-30). Also M. Schularick and T.M. Steger (2008) found that the key to increase the capital flow was improvement of public institutions management quality. Expanding the Lucas model, they also indicated the shortcomings of the capital market and the human capital quality (Schularick, Steger, 2008, pp. 10-11). Taking the model further, capital should also be flowing to the poorer borrowers. According to B. Armendariz de Aghion and J. Morduch (2009), money should be flowing from Wall Street to Harlem and then further to the poor rural communities in the Appalachian Mountains, and also from New Delhi to poverty-stricken villages in India. In their opinion, due to the law of diminishing marginal returns of capital, a shoe-maker working in the street or a woman selling flowers at a market stall should be able to offer their investors significantly higher returns from the capital invested in their businesses, compared to such global giants as General Motors, IBM, or Tata Group (Armendariz de Aghion, Morduch, 2009, p. 31).

If capital were ideally mobile, it should be invested in places characterised by a higher marginal productivity, i.e. from the rich to the poor. This means that the rich should be lending to the poor, or capital should be invested in enterprises in which the poorest will be employed. If this does not take place, we can say there is a certain paradox. According to A. Ashta (2007), there may be various reasons for this paradox, such as e.g. lack of certain additional elements, risks, market shortcomings or transaction costs. The missing elements also include the low level of education (including financial education) which affects the quality of human capital. Ashta (2007, p. 2) argues that it is the human capital and the education level that have an impact on the productivity. The differences in the levels of the human capital lead to differences in the labour efficiency of the rich and the poor. He distinguished the main reasons for the lack of capital flows to the poor: transaction costs, information asymmetry and other factors (Ashta, 2007, pp. 77-83), whereas B. Armendariz de Aghion and J. Morduch (2009, p. 76) described them as credit market imperfections, i.e. barriers in the flow of capital to the ones who need it the most.

The factor that contributes to the fact that capital is not invested in the poorest regions of the world is also the substantially higher cost related to investments made by the poor and unequal access to information (information asymmetry), which leads to negative selection, moral hazard and difficulties with monitoring. The problem is that the lender does not have sufficient knowledge of the project and its profitability (information asymmetry). The moral hazard issue occurs when the lender has no knowledge on the project implementation, its success and profitability (ex-ante moral hazard). Even if the project proves viable and pays off, there is a risk that the borrower will vanish with all the money (ex-post moral hazard). The above described problems may certainly be limited by regular monitoring. However, in the case of granting small loans to people from remote places, monitoring is costly and therefore it is not put in place by the lenders. 


\section{Operations of microfinance institutions}

The microfinance revolution has brought numerous benefits, and the idea conceived by M. Yunus was quickly transplanted to other countries. Thousands of financial institutions came into being, offering similar services. Yet, after some time, the idea of "the banker for the poor" became to some extent bastardised and distorted. New players became interested in the market, who so far had not really dealt with financial services for the poor, and, taking advantage of the substantial demand, offered loans at usury rates, and the microloans, instead of financing some specified goals (starting a business, purchasing a machine or cattle etc.) were used for financing the consumption.

The microfinance market in Europe, which differs in terms of the level and scope of support offered in the form of microcredits ${ }^{1}$ and other microfinance products, especially in comparison to the poorest countries, also faces some challenges. Similarly as in other regions, microfinance is aimed at two goals. The first is economic enablement of the beneficiaries, making it possible for them to start activities that generate income, and the second is achievement of social objectives enabling social integration, also including financial integration of individuals. Despite the adverse events of 2010-2012, microfinance has brought and will be bringing many benefits in both short and long term, such as (Lorenzi, 2016, pp. 11-12):

- strengthening the citizens and making it possible for them to use the financial instruments applied in market economy,

- reduction of unemployment and creating benefits in the local economy,

- increasing the investment attractiveness via taking over some of the risk,

- helping the local financial intermediaries to increase the value of granted loans,

- integration of public support for social inclusion,

- decreasing the public spending on social services, ensuring financing to groups of people in an unfavourable situation.

In many EU countries, microfinance institutions have been functioning successfully, while the number as well as the value of granted microloans has been rising. The significance of this form of support was also acknowledged by the European Commission which addressed microfinance institutions in its programs aimed at enhancing their potential, not only in terms of capital, but also human and organisational resources. In the EU, the main product is a microloan to support micro-entrepreneurs and natural persons. However, services offered by microfinance entities also include other forms of support that supplement the main product (Figure 1).

Microfinance development in the EU has resulted not only in diversification of microfinance products, including also savings, microinsurance, but also in a significant diversity of operations. European microfinance institutions provide support not only in the form of debt financial instruments, but also run a wider range of operations comprising financial education (aimed mainly at preventing excessive indebtedness), trainings for entrepreneurs, also with regard to development of business operations, and business incubators. The microfinance sector in the EU is quite heterogeneous, which is manifested by the variety of institutions offering microfinance support. The sector

\footnotetext{
${ }^{1}$ In the European Union, microcredit is understood and defined in two ways. The first one is a microcredit for an entrepreneur amounting to less than EUR 25,000 and granted to support the development of self-employment and micro-enterprises. The second is a microcredit for a natural person amounting to less than EUR 25,000 granted to support consumption needs such as, inter alia, education or health.
} 
is dominated by non-bank financial institutions (29.3\%) and NGOs or foundations (22.7\%), however, there are also community development financial institutions, religious institutions, and others (Figure 2).

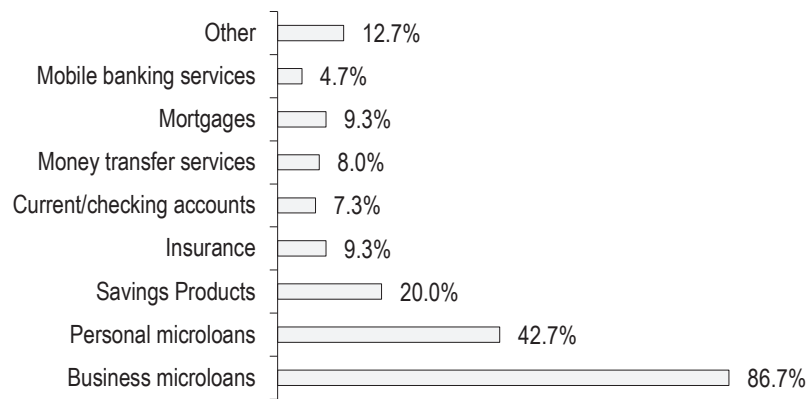

Figure 1. Financial products offered by microfinance institutions in the EU

Source: Bending, Unterberg, Sarpong (2014), p. 35.

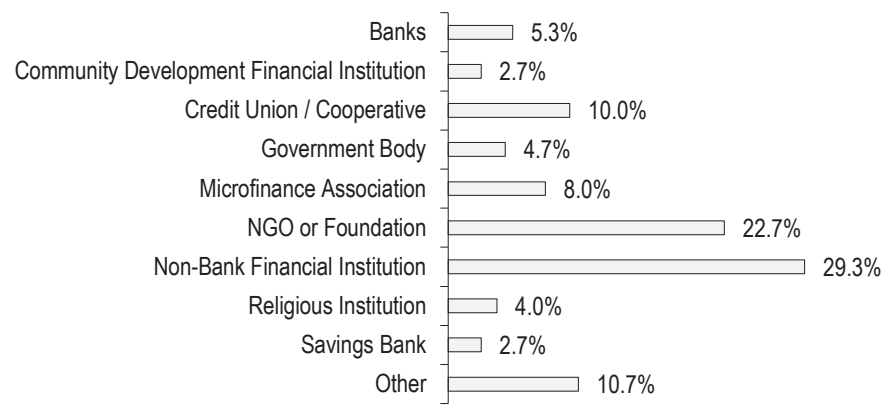

Figure 2. Kinds of microfinance institutions in the EU

Source: Bending, Unterberg, Sarpong (2014), p. 28.

The activities of microfinance institutions are a proof of their meaning and significance to economies, particularly on a local level. The popularity of the idea conceived by M. Yunus is marked by the variety of microfinance programs in Europe, also those financed with EU funds.

\section{Scenarios of microfinance and microfinance institutions development}

Summing up the deliberations regarding the idea and operation scopes of microfinance institutions, it may be said that they are gaining importance not only on the financial market, but first and foremost in social and economic development of many countries and regions, in the developing countries as well as in Europe and in Poland. However, in order to implement the mission and objectives of the movement initiated by M. Yunus, it is necessary to continually adjust to the current conditions, outline new challenges and react to ensuing global social 
changes, at the same time taking into account any developments taking place on local markets that are much more important to microfinance institutions.

The microfinance sector, which consists of many various institutions (private, public, commercial, non-profit, etc.), while becoming an integral and significant element of economic systems, simultaneously in many respects searches for new paths and objectives for their operations. The rapidly changing environment makes many entities look for new segments, markets and products so as to implement the idea of support to the fullest extent. The ensuing new tasks to be implemented and operating strategies have an impact on the development of microfinance entities in terms of organisation and product assortment, indicating the directions of development and implementation of the idea of microfinance. On the one hand, the market is quite difficult, for instance due to the significantly higher risk level and - as is often claimed - relatively low income in relation to that risk. On the other hand, the market is of strategic importance for regional and local development. Therefore, further and stable growth of the sector, corresponding to the market needs, is in the interest of all business entities.

Starting the commercialisation and then privatisation of microfinance institutions in the late 1980s and early 1990s marked the beginning of a new path for the microfinance movement - the path that left its mark on many microfinance entities all over the world. Management strategies started to be dominated by large-scale operations, losing the local, often unique character. Microfinance institutions became private entities focused on profit maximisation, thus killing the idea of getting the poor out of poverty. Moreover, many entities that so far had been microfinance-oriented turned into institutions focused on the financial market, striving to maximise the results of their operations. The most important goal of many microfinance institutions became increasing the stock value via maximisation of short-term results. According to M. Bateman, this way of understanding the idea of microfinance, based on full commercialisation, led to "the death of microfinance" (Bateman, 2010, pp. 123-124). The ensuing situation forced many entities to redefine their objectives and indicate new directions of microfinance development.

After a period of rapid growth followed by a decrease in profitability, the changed approach made it possible to understand the idea of microfinance and to combine commercial goals with social goals. To enable further growth of microfinance, in view of the achievements made so far by the sector, it is possible to propose scenarios and directions of development with regard to the source of the loan capital. The solution appears to consist of the three scenarios of microfinance institutions development:

- commercial scenario,

- social scenario,

- mixed scenario.

The first scenario - named commercial - is based on the assumption that the operations of microfinance institutions are financed with predominantly private capital and are aimed at achieving commercial goals (Figure 3). As a result of applying this scenario, microfinance institutions become profit-oriented and gain an optimum return on invested capital. In this model, the institutions may obtain capital from various sources, yet the dominating source is the financial market along with private financial institutions, operating on commercial principles. This does not exclude a possibility of obtaining funding from donators (sponsors) and public authorities, who will not strive to obtain the maximum possible rate of return at any cost. Nevertheless, the dominating place in the capital funding structure is held by private, commercial capital, which requires microfinance institutions to maximise their profits. This direction may bring adverse effects in the form of excessive indebtedness of households. Obviously, this solution should not be used in relation to the poorest. This scenario might be implemented for a target group 
consisting of wealthier customers who are not affected by social and financial exclusion, and of "healthy" businesses with stable positions. Operations of this type may bring short-term benefits, however, in a long run, due to their nature, they will lead to unfavourable changes in the lives of the poor.

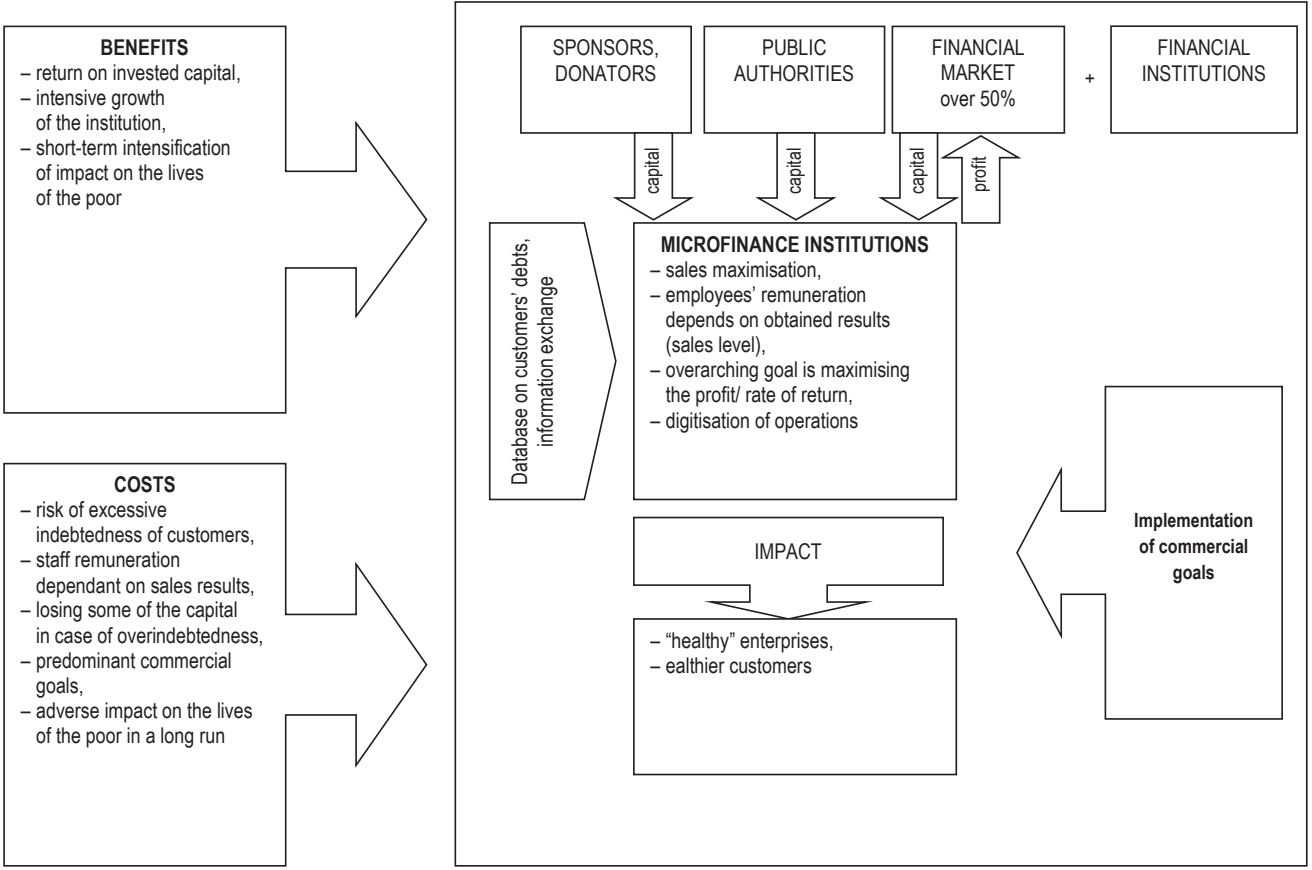

Figure 3. Commercial scenario of microfinance institutions development

Source: own work.

The second - the most desirable scenario from the point of view of customers - is the social scenario (Figure 4). It is characterised by predominance of public capital in financing the MFls operations, and it is focused on implementation of social goals. Even though the institutions that develop in compliance with this scenario are not profit-oriented, they are supposed to be financially self-sufficient and they should increase their capital in order to expand their operations. No dividends are stipulated, and the profits should be used to increase the capital or establish special funds for unforeseeable events. Institutions operating in accordance with this model are expected to support, to the greatest extent possible, the people who need their support the most. Apart from the poorest people, attention should be focused also on women, young people, national minorities and immigrants. Another characteristic of the scenario is also a wide range of flexible microfinancial products, tailored to the needs of each group. As a result of focusing on the impact on the community, there is a risk of losing some of the capital, however, the need to strive to balance the operations and a secure lending policy, aided by other microfinancial products along with trainings and education, are expected to prevent the problem. This model does not exclude investing 
any private (commercial) capital in microfinance institutions, however, they may not lead to total commercialisation of the entity.
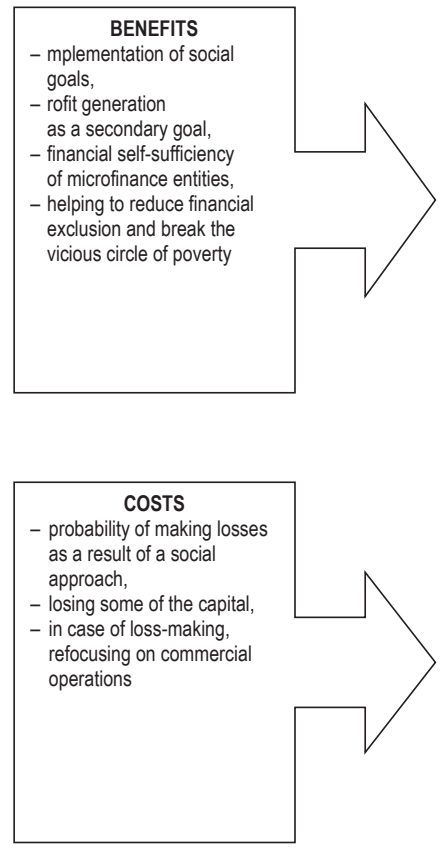

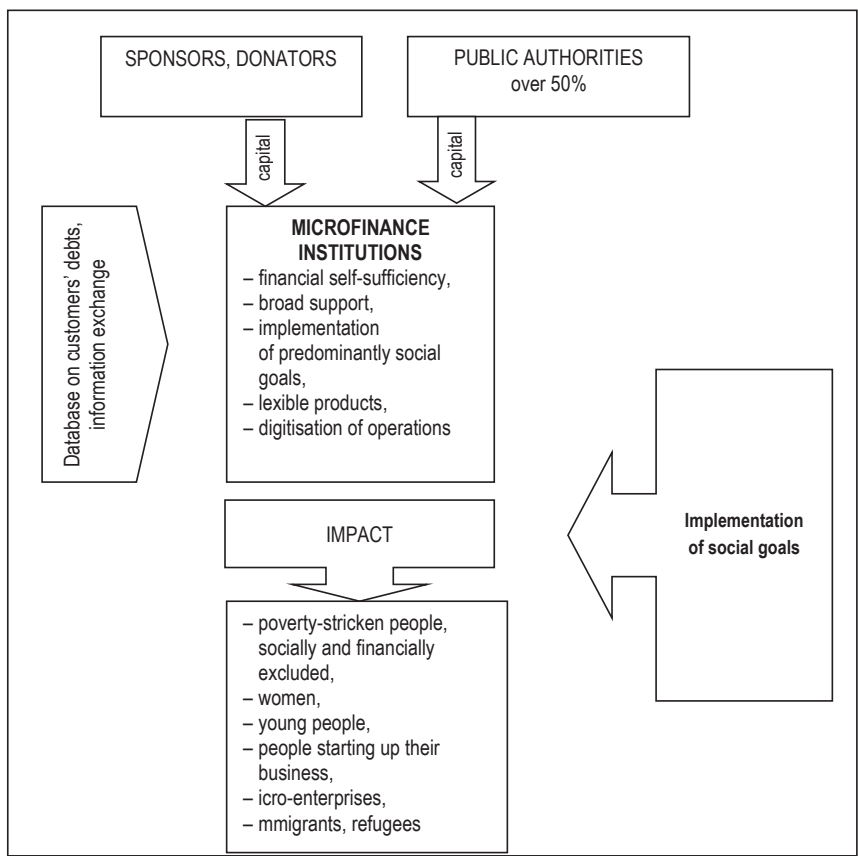

Figure 4. Social scenario of microfinance institutions development

Source: own work.

The third scenario constitutes a certain compromise between the two former ones, as it assumes coimplementation of social and commercial goals, where the former kind of goals is predominant, which is a condition of retaining the idea of microfinance (Figure 5). In the mixed model, the capital may be sourced from public funds and from donators, but also from the financial market or commercial microfinance institutions. However, the main source of capital is the funding provided by public institutions, and the objective of such an entity is providing help to the most poverty-stricken people. This may be the reason why commercial external investors do not show much interest in this model. There is a risk that any entities that intend to continue their microfinance operations will be striving toward commercialisation, which will lead to implementation of the commercial scenario. However, the possibility of social goals implementation, which helps establish and support a positive image, should incline the commercial sector to engage funds in entities of this type. This model appears to be the most viable in terms of implementation, as it is able to meet expectations of both the public sector and partially the private sector, and at the same time bring many benefits.

The described scenarios may neglect some aspects of their operations. Still, they indicate the directions which microfinance institutions may follow and point to those that are the most desirable from both social and economic point of view, also taking into account the local development aspect. In view of the nature of microfinance 
operations it seems that it is the local and regional development that should be another objective of microfinance entities' operations.

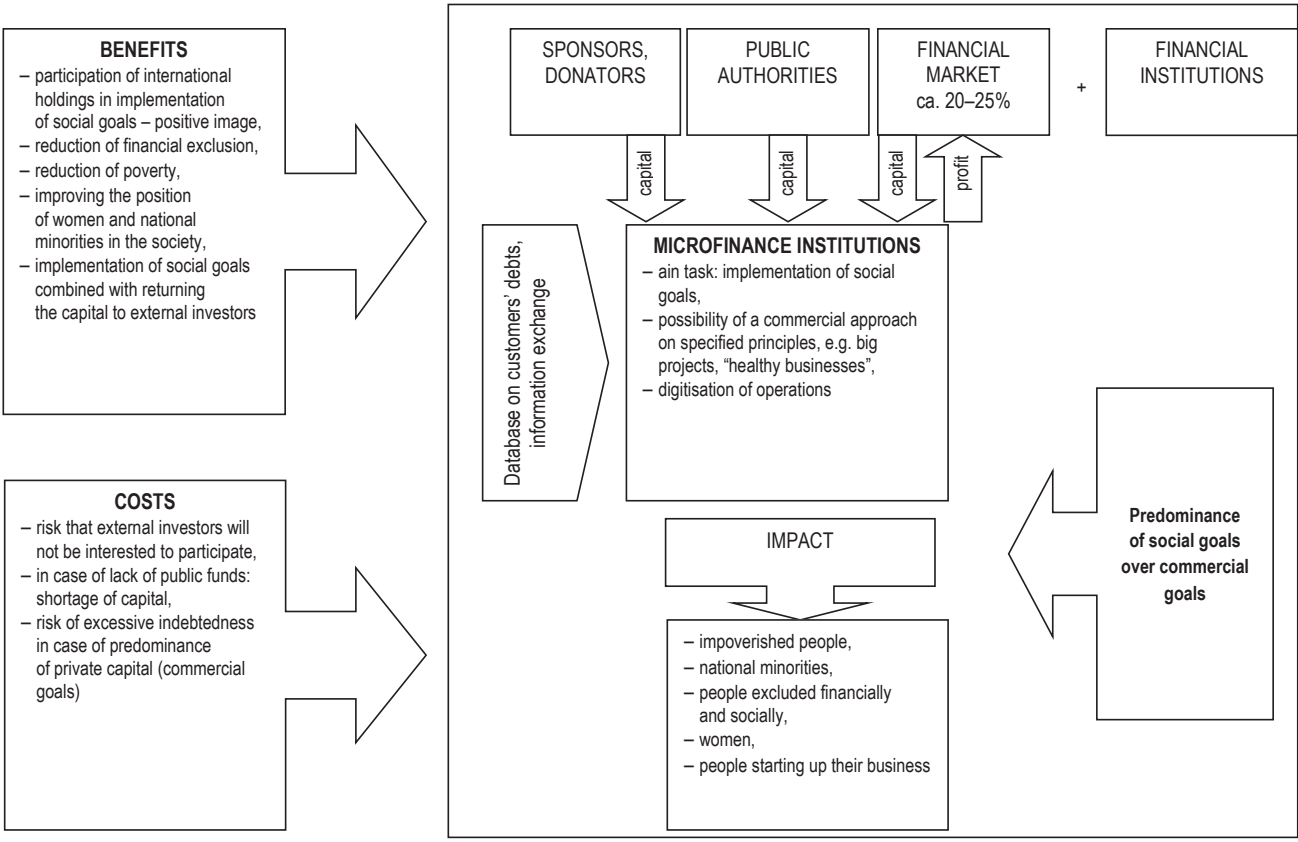

Figure 5. Mixed scenario of microfinance institutions development

Source: own work.

\section{Conclusions}

Microfinance institutions are now present not only in the poorest countries, but also in developed countries, which is exemplified by their significant popularity in the European Union. Their significance and operation should be addressed in many detailed documents and strategies which would indicate the nature of their operations. The importance of microfinance is manifested not only by awarded prizes, but also by including microfinance institutions development in programmes and initiatives financed with EU funds. Another step should be addressing the issues in documents prepared at the national and then regional level. It is in the interest of each region to have an efficient and effective network of microfinance institutions to serve their economic and social goals. This refers not only to the existing loan funds and guarantee funds, but first and foremost to establishing efficient entities that will be supporting the poorest people who are subject to exclusion, who have an idea for starting up a business, and who may become clients of loan and guarantee institutions in the future. This is about helping people so that they do not have to use the services of the banking system that offers support, but on conditions which many a time contradict rationality of their decisions. 


\section{References}

Adamek, J. (2010). Mikrofinanse islamskie - założenia, produkty, praktyka. Warszawa: CeDeWu.pl.

Alińska, A. (2017). Instytucje mikrofinansowe na rynku usług finansowym. Prace Naukowe Uniwersytetu Ekonomicznego we Wrocławiu, 478.

Armendariz de Aghion, B., Morduch, J. (2207). Ekonomia mikrofinansów. Gdańsk: Wydawnictwo AnWero.

Ashta, A. (2007). An Introduction to Microcredit: Why Money is flowing from the rich to the poor. Burgundy School of Business, CEREN Working Papers 21.

Bateman, M. (2010). Why doesn't Microfinance Work? The Destructive Rise of Local Neoliberalizm. London-New York: Zed Books,.

Bending, M., Unterberg, M., Sarpong, B. (2012). Overview of the Microcredit Sector in the European Union. European Microfinance Network, December.

Gonzalez, A., Rosenberg, R (2006). The State of Microfinance - Outreach, Profitability and Poverty. Findings from a database of 2600 microfinance institutions, Presentation at World Bank Conference on Access to Finance.

Lorenzi, M. (2016). Microcredit in the European Union: A Feasible means for business growth and fair access to credit. ECPR 8th PanEuropean Conference on the European Union, Trento.

Microcredit Networks and Existing National Legislations with a View to the Implementation of the Microfinance Instrument (2010). Directorate General For Internal Policies, Directorate A: Economic and Scientific Policies Employment and Social Affairs, European Parliament, IP/A/EMPL/NT/2009-08.

Montiel, P.J., College, W. (2006). Obstacles to Investment in Africa: Explaining the Lucas Paradox. Paper presented at the high-level seminar: Realizing the Potential for Profitable Investment in Africa Organized by the IMF Institute and the Joint Africa Institute, Tunis.

Schularick, M., Steger, T.M. (2008). The Lucas Paradox and the Quality of Institutions: Then and Now. Diskussionsbeiträge des Fachbereichs Wirtschaftswissenschaft der Freien Universität Berlin, Volkswirtschaftliche Reihe.

Cite this article as: Pluskota, P. (2018). Microfinance and microfinance institutions - development directions and prospects. European Journal of Service Management, 3 (27/1), 223-232. DOI: 10.18276/ejsm.2018.27/1-28. 